\title{
ARVC vagy myocarditis?
}

\section{Clemens Marcell1', Bódi Annamária', Vágó Hajnalka², Merkely Béla², Csanádi Zoltán', Tóth Attila²}

\author{
'Debreceni Egyetem, Klinikai Központ, Kardiológiai és Szívsebészeti Klinika, Debrecen \\ ${ }^{2}$ Semmelweis Egyetem, Városmajori Szív- és Érgyógyászati Klinika, Budapest \\ Levelezési cím: \\ Dr. Clemens Marcell, Debreceni Egyetem, Klinikai Központ, Kardiológiai és Szívsebészeti Klinika \\ 4032 Debrecen, Móricz Zsigmond krt. 22. E-mail: marcellclemens@gmail.com
}

30 éves férfi betegünk tartós kamrai tachycardiát követően került felvételre Klinikánkra, ahol a klinikum alapján a ritmuszavar hátterében elsősorban akut myocarditis merült fel, amelyet az elvégzett szív MR-vizsgálat is igazolt. Azonban az MR-en látható kép az akut szívizomgyulladás mellett egyéb strukturális alapbetegség fennállását is valószínűsítette, amelyet a két hónappal később, a miokardiális ödéma visszahúzódását követően, elvégzett kontroll szív MR-vizsgálat is megerősített. Az MR lelet, a nyugalmi 12 elvezetéses és kamrai tachycardia alatti EKG-kép alapján kétkamrás aritmogén jobb kamrai cardiomyopathia (ARVC) diagnózisát állítottuk fel.

Az ARVC fennállása hajlamosít akut myocarditis epizódok kialakulására, melyek jellemzően az alapbetegség progreszszióját okozzák. Nem ritka, hogy maga az alapbetegség is egy ilyen akut gyulladásos epizód kapcsán kerül felismerésre. ARVC-ben egyes génmutációk (elsősorban a DSP) gyakoribb társulást mutatnak az akár visszatérően is jelentkező akut carditis epizódokkal.

Kulcsszavak: aritmogén jobb kamrai cardiomyopathia, szívizomgyulladás, szív MR, kamrai tachycardia

\section{ARVC or myocarditis?}

A 30-year-old male was referred to our Department due to ventricular tachycardia. Based on symptoms, echocardiography and laboratory examinations acute myocarditis was diagnosed which was confirmed by cardiac MRI. Besides myocarditis, MRI also indicated the presence of an underlying myocardial disease which was also verified by a control examination performed 2 months later, following the resolution of myocardial edema. Results of the MRI, resting 12lead ECG and ECG characteristics of ventricular tachycardia fulfilled the diagnostic criteria of arrhyhtmogenic right ventricular cardiomyopathy (ARVC).

ARVC predisposes to episodes of acute myocarditis resulting in deterioration of the underlying cardiomyopathy. Based on case reports, it is not uncommon that ARVC is first diagnosed during an episode of acute inflammation. Certain gene mutations (most commonly DSP) carry an increased risk for myocarditis in ARVC.

Keywords: arrhythmogenic right ventricular cardiomyopathy, myocarditis, cardiac MRI, ventricular tachycardia

\section{Esetismertetés}

30 éves férfi betegünk kórelőzményében nagyobb megbetegedés nem szerepelt. 2018 februárjában két napja fennálló láz, hányás, kifejezett gyengeség miatt hospitalizálták sürgősségi osztályon, ahol EKGján 180/perc monomorf kamrai tachycardiát észleltek, amelyet hemodinamikai instabilitás miatt rövid altatásban DC-sokk leadásával szüntettek. További kivizs- gálás céljából másnap került felvételre Klinikánkra. Érkezésekor kardiorespiratorikusan kompenzált volt, fizikális vizsgálattal lényegében negatív státuszt észleltünk. Nyugalmi 12 elvezetéses EKG-ján (1. ábra) normofrekvens sinusritmus mellett kifejezett repolarizációs eltérések ábrázolódtak, elsősorban a mellkasi elvezetésekben, illetve a $V_{1}$-elvezetésben kiszélesedő „s” hullámok mellett epszilon hullámok is láthatóak voltak. Felvételi laborokból jelentősen emelkedett kar- 


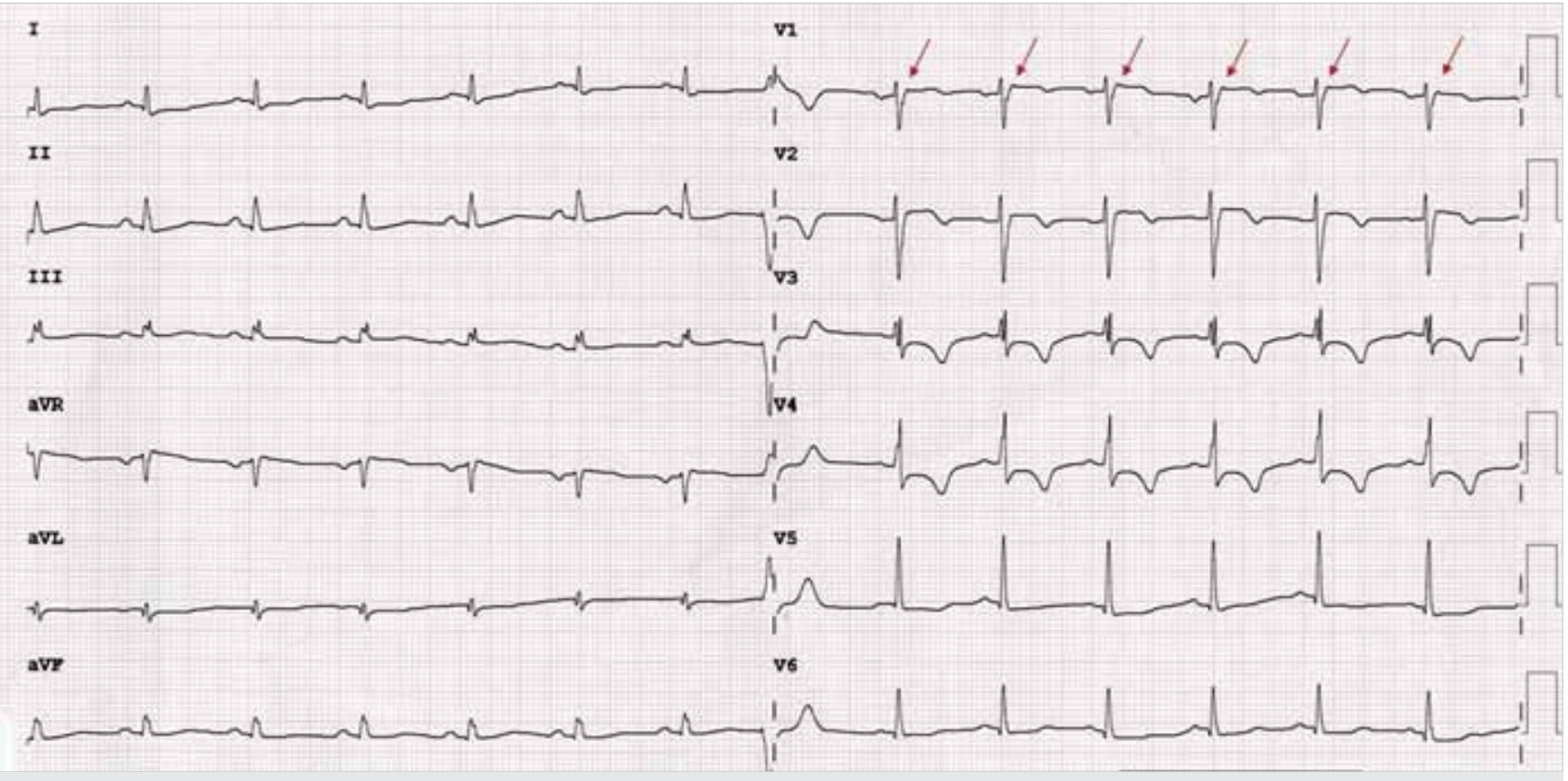

1. ÁBRA. Felvételi, 12 elvezetéses EKG. A normofrekvens sinusritmus mellett diffúz repolarizációs eltérések láthatók az aritmogén jobb kamrai cardiomyopathiára jellemző EKG-eltérésekkel: $\mathrm{V}_{1}$-elvezetésben az epszilon hullámok (nyilak), illetve az „s" hullám kiszélesedő felszálló szára

diális nekroenzim szintek (cTnT: 3464 ng/l, CK: 1939 U/I) és minimálisan emelkedett gyulladásos markerek emelendők ki (CRP: 5,4 mg/l). Echokardiográfia közepes mértékben csökkent bal- és jobbkamra-funkciót írt le a bal kamra diffúz hipokinezisével és elsősorban a jobb kamra tágulatával. Az iszkémiás etiológia kizárása céljából elvégzett koronarográfia ép koszorús- érrendszert igazolt. Felvételét követő első 4 napban 3 alkalommal jelentkezett tartós monomorf kamrai tachycardia (2. ábra), ami utolsó alkalommal keringésmegingást, eszméletvesztést okozott, a sinusritmus DC-sokk leadását követően állt helyre. Az etiológia tisztázása céljából szív MR-vizsgálatot végeztünk, amely mindkét kamrában akut myocarditisre utaló fol-

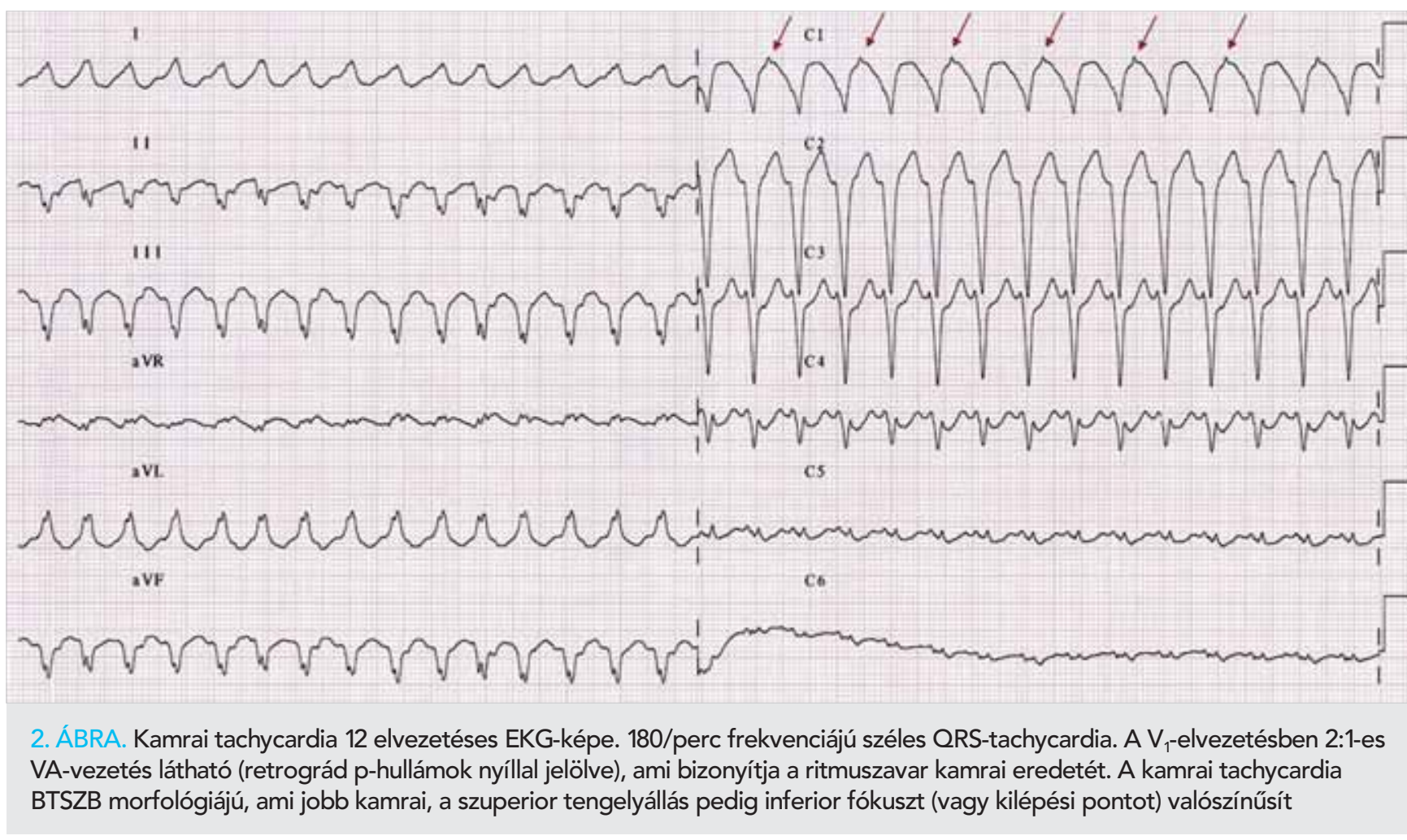




\begin{tabular}{|c|c|c|}
\hline Vizsgált paraméter & Akut szív MR & Kontroll szív MR \\
\hline LVEF (\%) & 44 & 43 \\
\hline LVESVi $\left(\mathrm{ml} / \mathrm{m}^{2}\right)$ & 70 & 70 \\
\hline LVEDVi $\left(\mathrm{ml} / \mathrm{m}^{2}\right)$ & 126 & 123 \\
\hline LVMi $\left(\mathrm{g} / \mathrm{m}^{2}\right)$ & 70 & 60 \\
\hline RVEF (\%) & 42 & 43 \\
\hline RVESVi (ml/m²) & 76 & 74 \\
\hline RVEDVi $\left(\mathrm{ml} / \mathrm{m}^{2}\right)$ & 131 & 130 \\
\hline
\end{tabular}

LVEF: left ventricular ejection fraction - bal kamra ejekciós frakció; LVESVi: left ventricular end systolic volume index - bal kamra végszisztolés térfogat index; LVEDVi: left ventricular end diastolic volume index - bal kamra végdiasztolés térfogat index; LVMi: left ventricular mass index - bal kamra izomzat tömegindex; RVEF: right ventricular ejection fraction - jobb kamra ejekciós frakció; RVESVi: right ventricular end systolic volume index - jobb kamra végszisztolés térfogat index; RVEDVi: right ventricular end diastolic volume index - jobb kamra végdiasztolés térfogatindex

tos miokardiális ödémát és non-iszkémiás jellegű késői kontraszthalmozást mutatott (3. ábra $A, B$ ). Bár a látott képet a gyulladás okozta ödéma uralta, a myocarditisen túl egy meglévő alapbetegség fennállása is valószínűnek tűnt, amelynek diagnózisában egy későbbi, a miokardiális ödéma visszahúzódását követő kontroll MR elvégzését alapvető fontosságúnak tartottunk. A keringésmegingást okozó kamrai ritmuszavarok miatt azonban implantálható kardioverter defibrillátor (ICD) beültetése szintén elengedhetetlen volt. A tervezett kontroll szív MR-vizsgálatra tekintettel egy MR kondicionális készüléket (Biotronik Intica VR-T DX ProMRI) implantáltunk a hozzá tartozó szintén MR kondicionális sokk elektródával (Plexa ProMRI DF-1 S DX 65/17). A készüléket a szokásostól eltérően a jobb szubklavikuláris régióba ültettük be, ezáltal csökkentve az ICD-telep okozta mütermékek zavaró hatását. Kéthónapos klinikailag eseménymentes időszakot követően történt meg a kontroll MR-vizsgálat, ami a miokardiális ödéma eltűnését igazolta, azonban mindkét kamra funkciója továbbra is csökkent maradt (1. táblázat), kiterjedt, elsősorban a midmiokardiális és szubepikardiális rétegeket érintő kontrasztanyag-halmozással (3. ábra $C, D$ ). A térfogatok is a mérési hibahatáron belül maradtak. Az izomzat tömeg csökkenése hátterében az ödéma elmúlása feltételezhető. Önmagában az MR-kép alapján leginkább kétkamrás aritmogén jobb kamrai cardiomyopathia (ARVC) lehetősége merült fel. A Task Force rendszerben az MR-vizsgálat által igazolt jobb kamrai funkció csökkenés, a nyugalmi EKG-n látható epszilon hullám, és a nem kifolyó traktus kiindulású tartós jobb kamrai tachycardia által összesen 3 major kritérium jelenléte teljesült, ami alapján az ARVC diagnózisa felállítható volt. A beteg az ICD-implantáció óta eltelt 5 hónapban klinikailag panaszmentes, kamrai ritmuszavara, ICD müködése nem volt. Genetikai vizsgálatra vérvétele megtörtént, értékelése jelenleg folyamatban.

\section{Megbeszélés}

Az ARVC egy genetikus, elsősorban a desmosomális proteineket kódoló gének mutációján alapuló betegség, ami klinikailag a kamrai myocyták közötti fizikai kapcsolatok megszakadásával, a sejtek közötti jelátviteli utak károsodásával és következményesen sejtelhalással, az érintett myocardium régió zsíros-kötőszövetes elfajulásával jár. A betegség klasszikus formájában döntően a jobb kamra érintettsége a jellemző, de egyes variánsok a két kamra hasonló, vagy elsősorban a bal kamra érintettségével járnak. Genetikai vizsgálattal az ARVC-s esetek kb. 50\%-ában lehet kóroki mutációt igazolni. Leggyakrabban a plakophilin-2 (PKP2) génmutáció fordul elö (az esetek kb. 10-45\%-áért felelős), amelyet a desmoplakin (DSP; 10-15\%), desmoglein-2 (DSG2; 7-10\%), és a desmocollin-2 (DSC2; 2\%) mutációi követnek (1). Diagnózisához a 2010-ben publikált módosított kritériumrendszer nyújt segítséget, ahol a képalkotó vizsgálatok (echo/MR), szövettani eredmények, nyugalmi és ritmuszavar alatti EKG-eltérések, illetve családi anamnesztikus adatok alapján állítható fel a diagnózis (2). Fontos azonban megemlíteni, hogy a fenti kritériumok elsősorban a klasszikus, dominálóan jobb kamrai érintettséggel járó ARVC diagnózisára alkalmasak, azonban a döntően a bal kamrát érintő formák azonosításában csökken a szenzitivitásuk (3).

Az ARVC kórlefolyásában a genetikai tényezők mellett környezeti faktorok, vírusinfekciók is szerepet játszhatnak. ARVC-s betegekből származó szövettani minták akár $60-88 \%$-ában is kimutathatók gyulladásos infiltrátumok (4). Az egyre bővülő irodalmi adatok alapján az ARVC talaján kialakuló myocarditis nem két ritka betegség véletlen társulása, hanem az ARVC okozta strukturális eltérések egy fokozott hajlamot jelentenek következményes szívizomgyulladás kialakulására (4), és ezek az akut epizódok következményesen hozzájárulnak az alapbetegség progressziójához; sőt egyes szerzők az ARVC természetes kórlefolyásának részeként tekintenek az, esetenként ismétlődően jelentkező, carditis epizódokra (4). Korábbi esetközlések (4, 5, 6) alapján nem ritka, hogy maga az ARVC diagnózisa is egy akut carditis epizód kapcsán kerül felállításra, csak úgy, mint esetünkben történt. Az akut gyulladásos epizódhoz társuló fokozott aritmogenitást, társuló kamrai tachycardiákat több korábbi esetben leírtak $(5,6)$, amelyek a carditis gyógyulását követően lényegesen megritkultak, vagy eltűntek. Esetünkben, az akut szakban három különböző kamrai tachycardia morfológia is megfigyelhető volt, aminek hátterében valószínủleg a kiterjedt, bal és jobb kamrát is érintő hegesedés állt. Bár az utánkövetési idő egyelőre rövid a hazabocsátása óta betegünk ritmuszavarmentes, hasonlóan a fenti esetekhez.

További jellegzetessége az ARVC talaján kialakuló carditisnek, hogy szoros összefüggést mutat az alapbetegségért felelős genetikai mutációval: egy retrospektív 


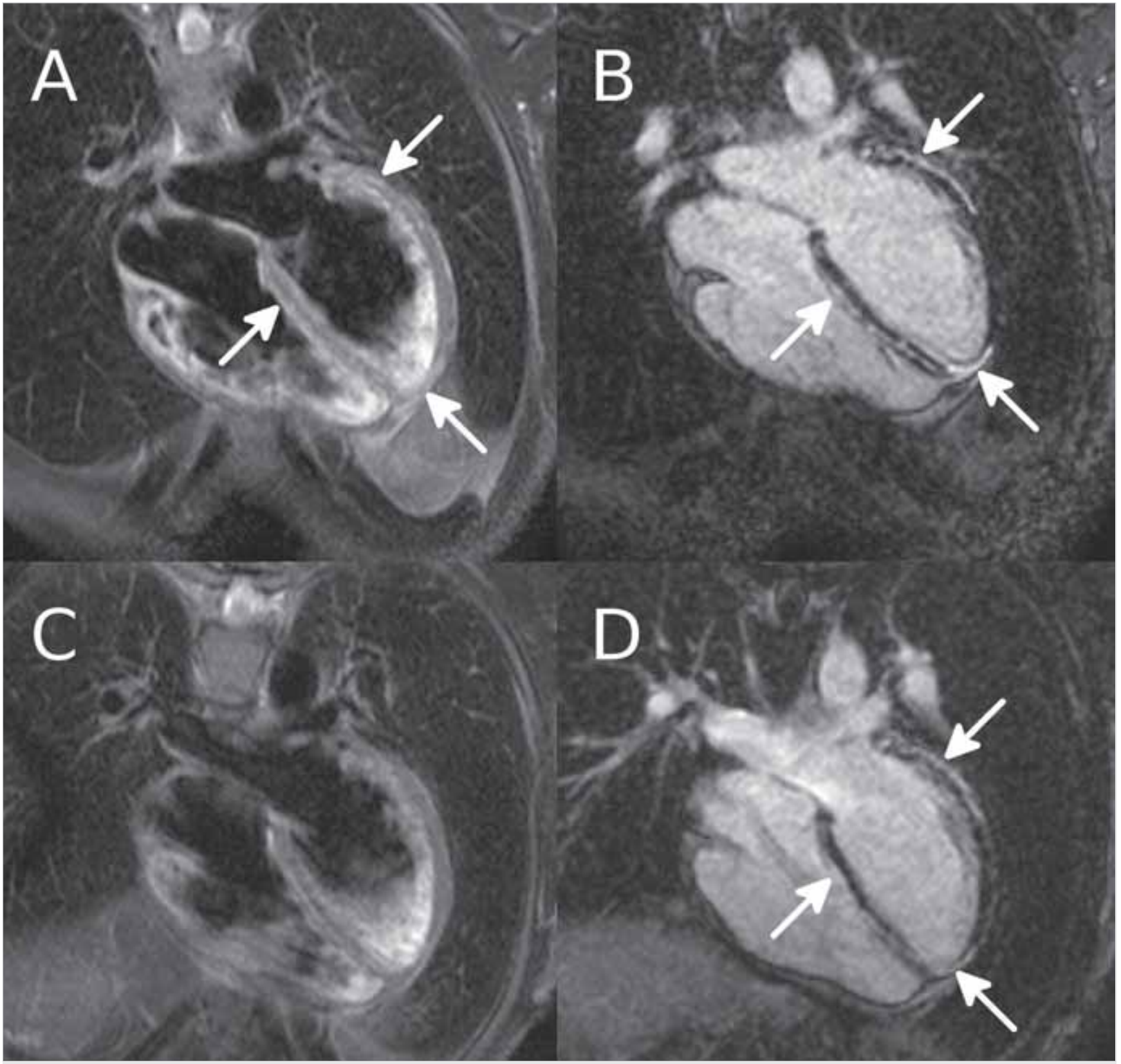

3. ÁBRA. Szív MR. Felső sorban: akut szív MR-vizsgálati képek; alsó sorban: kontroll szív MR-vizsgálat képei. Az ödéma és a foltos késői halmozás mintázata noniszkémiás eloszlást mutat. $A: T_{2}$-súlyozott, zsírelnyomásos, vérelnyomásos TSE-felvétel az ödéma kimutatására (fehér nyilak). B: 10 perccel a kontrasztanyag adását követően készült inverziós TFE-kép a késői halmozás megjelenítésére (fehér nyilak). C: kontroll $\mathrm{T}_{2}$-súlyozott, zsírelnyomásos TSE-felvételen ödéma már nem látható. $\mathrm{D}$ : kontroll késői halmozású képen még mindig több lokalizációban észlelhető maradvány heg

kohorsz vizsgálatban, ahol manifeszt ARVC-s és mutációhordozó betegek átlagosan közel 3 éves utánkövetése során 3,5\%-ában alakult ki akut szívizomgyulladás, az ARVC hátterében a 7 érintett beteg genetikai vizsgálata során 5 esetben a DSP-génmutáció igazolódott. Klinikailag a DSP-mutáció hordozók esetében gyakrabban látni bal kamrai érintettséget (akár izoláltan is), ami szintén megfigyelhető esetünkben, ahol az MR-vizsgálat mindkét kamra kiterjedt hegesedését mutatta.

$\mathrm{Az}$ akut myocarditis kimutatásában nagy segítséget nyújt a szív MR-vizsgálóeljárás, összehasonlítva más diagnosztikus lehetőségekkel, mint az EKG, a nekroenzimek, vagy akár a szívizom-biopszia (7). A T1-, és T2-mapping technikák elterjedésével a szív MR diagnosztikus pontossága még tovább fog növekedni (8). Heveny szívizomgyulladás gyanúja esetén érdemes minél hamarabb - lehetöleg 7 napon belül - elvégezni a vizsgálatot, ugyanis a szokványos enyhe esetekben hamar nehezen kimutathatóvá válhat a szívizom-ödéma és a késői halmozás. Krónikus szívizomgyulladás esetén már korántsem teljesít ilyen jól a szív MR, még mapping technikák használata ellenére sem (9). 
Az ARVC kórisme kimondásában is rendszerint fontos szerep jut a szív MR-nek. A Task Force által kidolgozott 2004-es kritériumrendszert 6 év tapasztalatai alapján 2010-ben megújították (10). A szív MR-kritériumok a jobb kamra ejekciós frakció és a jobb kamra végdiasztolés térfogatindex meghatározásán alapulnak, továbbá jobb kamrai falmozgászavar jelenlétét kell kimutatni. Férfiak esetén a térfogatindex minor határa $100 \mathrm{ml} / \mathrm{m}^{2}$, a major határ $110 \mathrm{ml} / \mathrm{m}^{2}$. A módosított rendszerben már nem szerepel a jobb kamrai zsíros átépülés igazolása, mivel a tapasztalatok szerint technikailag nem megbízható. A kamrafal késői halmozásának jelenléte még nem eleme a kritériumrendszernek, de várhatóan azzá fog válni. Az igazán aritmogén léziók ugyanis fibrotikusak, a kötőszövetes átépülés pedig késői halmozással detektálható. Az ARVC-s esetek több mint 60\%-ában mindkét kamra érintett, ezért újabban javasolják az aritmogén cardimyopathia elnevezés használatát (11).

\section{Következtetések}

Az ARVC fennállása hajlamosít akut myocarditis epizódok kialakulására, amelyek az alapbetegség progreszszióját okozhatják. Nem ritka, hogy maga az alapbetegség is egy ilyen akut gyulladásos epizód kapcsán kerül felismerésre. Egyes génmutációk (elsősorban a DSP) gyakoribb társulást mutatnak az akár visszatérően is jelentkező akut carditis epizódokkal.

\section{Irodalom}

1. Corrado D, Link MS, Calkins $H$. Arrhythmogenic right ventricular kardiomiopathy. N Engl J Med 2017; 376: 61-72. doi: 10.1056/ NEJMra1509267

2. Marcus FI, McKenna WJ, Sherrill D, Basso C, Bauce B, Bluem- ke BA. Diagnosis of arrhythmogenic right ventricular cardiomiopathy/dysplasia: proposed modification of the task force criteria. Circulation 2010; 121(13): 1533-41. doi: 10.1161/CIRCULATIONAHA.108.840827

3. Basso C, Pilichou K, Bauce B, Corrado D, Thiene G. Diagnostic Criteria, Genetics, and Molecular Basis of Arrhythmogenic Cardiomyopathy. Heart Fail Clin 2018; 14(2): 201-213. doi: 10.1016/j. hfc. 2018.01.002

4. Lopez-Ayala JM, Pastor-Quirante F, Gonzalez-Carrillo J, et al. Genetics of myocarditis in arrhythmogenic right ventricular dysplasia. Heart Rhythm 2015; 12(4): 766-73. doi: 10.1016/j.hrthm.2015.01.001 5. Huttin $O$, Frikha Z, Brembilla-Perrot B, et al. Acute myocarditis presenting with ventricular arrhythmias: the role of CMR in the differential diagnosis of ARVD. Intern Med 2013; 52(17): 1915-8. doi: 10.2169/internalmedicine.52.0462

6. Ponsiglione A, Puglia M, Morisco C, et al. A unique association of arrhythmogenic right ventricular dysplasia and acute myocarditis, as assessed by cardiac MRI: a case report. BMC Cardiovasc Disord 2016; 16(1): 230. doi: 10.1186/s12872-016-0412-2

7. Lurz P, Eitel I, Adam J, et al. Diagnostic Performance of CMR Imaging Compared With EMB in Patients With Suspected Myocarditis. JACC: Cardiovascular Imaging 2012; 5(5): 513-24. doi: 10.1016/j. jcmg.2011.11.022

8. Luetkens JA, Doerner J, Thomas DK, et al. Acute Myocarditis: Multiparametric Cardiac MR Imaging. Radiology 2014; 273(2): 38392. doi: $10.1148 /$ radiol.14132540

9. Lurz P, Luecke C, Eitel I, Föhrenbach F, et al. Comprehensive Cardiac Magnetic Resonance Imaging in Patients With Suspected Myocarditis. JACC 2016; 67(15): 1800-11. doi: 10.1016/j. jacc. 2016.02.013

10. Marcus FI, McKenna WJ, Sherrill D, et al. Diagnosis of Arrhythmogenic Right Ventricular Cardiomyopathy/Dysplasia. Circulation 2010, 121(13): 1533-41. doi: 10.1161/CIRCULATIONAHA.108.840827

11. Haugaa KH, Basso C, Badano LP, et al. Comprehensive multi-modality imaging approach in arrhythmogenic cardiomyopathy - an expert consensus document of the European Association of Cardiovascular Imaging. EHJ Cardiovascular Imaging 2017; 18(3): 237-53. doi: 10.1093/ehjci/jew229 